\title{
Food value of some populations of Algerian annual alfalfa
}

\author{
F. Alane ${ }^{\mathrm{A}^{*}}$, R.Chabaca $^{\mathrm{b}}$, A. Abdelguerfi ${ }^{\mathrm{C}}$ \\ anstitut National de Recherche d'Agronomie INRA A Baraki, Algeria. \\ bet cEcole National Supérieur Agronomique, El Harrach, Algeria \\ * Corresponding author. EM: alanefarida@hotmail.fr
}

Keywords: annual alfalfa, early flowering stage, chemical composition, digestibility

Publication date 29/02/2020, http://m.elewa.org/Journals/about-japs/

\section{$1 \quad$ ABSTRACT}

Fodder grown in Algeria occupies $20 \%$ of the total UAA (agricultural area use) of the country. They are dominated by so-called "dry" fodder. The conversion of northern fallow land and steppe to self-regenerating legumes in an annual Cereal / Medicago rotation system may increase it. At the early flowering stage, the results indicate that the mineral content of the annual alfalfa is consistent; it varies from 9 to $14 \%$ of the DM (Dry matter). The species $M$. truncatula $(\operatorname{Tr} 238)$ has the highest value $(18 \%)$, which decreases the organic matter content. The nitrogen content is high with a maximum of $29 \% M$ ciliaris(S5) and a minimum of 20\% M. intertexta (I107): the $M$. ciliaris species is the best provided in MAT (total nitrogenous matter) with an average of $27 \%$ against $M$. intertexta: $23 \%$. The highest NDF (neutral detergent fibre) content, $46 \%$ of the MS (dry matter) is recruited among $M$. intertexta (I253) quite logically, ADF (acid detergent fibre) and ADL (lignin) follow with 21 and $9 \%$ as respective maximas for all populations. However, on average, the ADL content is only $5 \%$ with a minimum of $2.6 \%$ for $\mathrm{C} 2 \mathrm{M}$. ciliaris. It is interesting to note, the positive sign of the correlation between factors $\mathrm{N}$. of Rods / $\mathrm{m}^{2}$ and ADF: the amount of DM (thus indirectly lignin) increases in parallel with the age of the plant, as NDF and ADF. Considered first by test, the recorded digestibility values are equal to or greater than $70 \%$ : $75 ; 73 ; 74 ; 79$ (respectively for tests 1 to 4 ) and on average, 75\%. The average digestibility per species is 77; 73 and $75 \%$ for $M$ ciliaris, $M$ truncatula and $M$ intertexta. Variations between populations and species are low: 3.4 and 3.1\% respectively. The 20 or so populations of local annual alfalfa studied showed a great genetic variability of the studied parameters, which constitutes an important genetic capital in which the breeder could draw at leisure.

Abbreviations: $M A T$, total nitrogenous matter ; $A D F$, acid detergent fibre; $D M$, dry matter; $U A A$, agricultural area use,; $\mathrm{NDF}$, neutral detergent fibre; $N$. of Rods / $\mathrm{m}^{2}$, Number of Rods / $\mathrm{m}^{2}$.

\section{INTRODUCTION}

Fodder grown in Algeria is about $20 \%$ of the total UAA of the country (8million ha). Fodder crops are themselves dominated by so-called "dry" fodder that is consumed as hay form, the best-known association of the vetch-oats. The role of forage crops is largely linked to the role of livestock farming, which values it. The main obstacle to improving livestock production in Algeria is the poor feeding of livestock. Local populations are a living reservoir of plant material and selection of these populations may be an attractive route for breeding programs. The transformation of northern fallow land and steppe by self-regenerating legumes into an 
annual cereal / Medicago rotation system becomes a priority to occupy this area. The tests of the Ley farming system conducted from 1972 to 1978, although conclusive, were not continued (Abdelguerfi and AbdelguerfiBarrekia, 1987).According to Heyn (1963) and Greuter (2001) annual species are confined particularly to the Mediterranean region. Their distribution is discriminated by rainfall and to a lesser degree by the altitude and texture of the soil (Hassen et al., 1996). Many constraints prevent the extension of the local annual Medicago genus to Algeria. The conversion of northern fallow land and steppe to selfregenerating legumes in an annual Cereal /

\section{MATERIALS AND METHODS}

2.1 Plant material: The plant material used for this test is composed of 20 local populations of annual alfalfa one of which (01)
Medicago rotation system may increase it. Among these obstacles, the lack of research on their nutritional value. However, thanks to the in vitro digestibility in this study of 11 of them, which comes after the taking of the biometric parameters and the realization of the chemical composition of about twenty annual alfalfa, we begin to approach the field. Strictly essential because the goal is to make nourishing fodder. Knowing that a good diet can partially overcome a genetic deficit in animals. The populations that we studied belong to the species: M.intertexta, M. ciiliaris, M.polymorpha, M.truncatula and an introduced population belonging to M.muricoleptis.

is introduced from Syria (M.muricoleptis) and another perennial (M.sativa) Italian variety that is sold by the seed companies (Table .1).

Table 1: Origins of the studied species

\begin{tabular}{lccc}
\hline Species & codes & weight of 1000graines & origins \\
\hline M. intertexta & I1 & 5.77 & ENSA (2004) \\
M. ciliaris & C & 13.21 & ENSA (2004) \\
M. truncatula & Tr & 3.58 & ENSA (2004) \\
M. polymorpha & Poly & 3.24 & ENSA (2004) \\
M. muricoleptis & (Aus 106) & 6.26 & Turkie (2004) \\
Triade & & & 2.16 \\
$(2013)$ & & & ITGC \\
\hline
\end{tabular}

ENSA: National higher school of agronomy, ITGC: Technical institute of field crops

Seeding was done manually on 24/12/2014 at a rate of 80 seeds per population and per line. Each population is represented by 4 lines with three repetitions ( 3 blocks that is 12 lines per population). The layout is random. The surface area is $31488 \mathrm{~m}^{2}(5248 \mathrm{mx} 6 \mathrm{~m})$, the test is conducted in dry conditions and is constantly maintained, against weed infestations, by two tiller passages from the vegetative period to that of the beginning of flowering, followed by manual weeding.

2.2 Site characteristics and climatic environment: The experimental farm of ENSA is located at $30^{\circ} 8$ 'longitude, $36^{\circ} 43^{\prime}$ north latitude and at an altitude of $48 \mathrm{~m}$. The climate is a sub-humid coastal climate characterized by a cold and damp winter and a hot and dry summer. The climatic conditions of the 2014/2015 companion occurring respectively during the experimental period are given in Table 2. From January to June, during which most of the development of the plant under rainfed conditions takes place, the average temperature in May 2015 was around $18^{\circ} \mathrm{C}$ but colder in January and February in $20159.4^{\circ} \mathrm{C}$. By cons, a near drought in April. More details are given in Table 2. 
Table2: Climate data for 2013 and 2015

\begin{tabular}{|l|l|l|}
\hline \multirow{3}{*}{ Month } & $\mathbf{2 0 1 5}$ & Sum of rainfall (mm) \\
\cline { 2 - 3 } & Average of $\mathbf{T}^{\circ}$ & 98.9 \\
\hline January & 9.4 & 80.0 \\
\hline February & 9.6 & 96.3 \\
\hline March & 14.8 & 1.6 \\
\hline April & 17.7 & 28.4 \\
\hline May & 18.8 & 14.4 \\
\hline June & 22.4 &
\end{tabular}

Physicochemical analysis of samples taken from the soil at a depth of $20 \mathrm{~cm}$ and $40 \mathrm{~cm}\left(\mathrm{P}_{20}\right.$ and $\mathrm{P}_{40}$ ) before sowing gave a silty-clayey texture, low in nitrogen and organic matter and $\mathrm{pH}>7$ 23 (Table 3).

Table 3: Physico-chemical analysis of plots sown in 2012 and 2014

\begin{tabular}{|c|c|c|}
\hline \multirow[t]{2}{*}{ Parameters } & \multicolumn{2}{|c|}{ Year 2014} \\
\hline & P 20 & $\mathbf{P} 40$ \\
\hline Phosphorus (ppm) & 0.8115 & 0.6325 \\
\hline Average & \multicolumn{2}{|l|}{0.7220} \\
\hline Potassium $\mathrm{mg} / 100 \mathrm{~g}$ & 0.1750 & 0.1621 \\
\hline Average & \multicolumn{2}{|l|}{0.1685} \\
\hline $\mathrm{Ph}$ & 7.22 & 7.75 \\
\hline Average & \multicolumn{2}{|l|}{7.485} \\
\hline EEC & 0.1526 & 0.0654 \\
\hline Average & \multicolumn{2}{|l|}{0.109} \\
\hline Nitrogen $\%$ & 0.1121 & 0.0934 \\
\hline Average & \multicolumn{2}{|l|}{0.1027} \\
\hline Organic material (\%) & - & - \\
\hline $\mathrm{CaCo3}(\%)$ & 7.3330 & 7.0000 \\
\hline Average & \multicolumn{2}{|l|}{7.1665} \\
\hline$($ Clay $\%)$ & 21.2500 & 21.5000 \\
\hline Average & \multicolumn{2}{|l|}{21.375} \\
\hline Silt $(\%)$ & 40.4900 & 39.7200 \\
\hline Average & \multicolumn{2}{|l|}{39.605} \\
\hline Sand $(\%)$ & 38.2500 & 38.7800 \\
\hline Average & \multicolumn{2}{|l|}{38.51} \\
\hline Texture & $\mathrm{L}$ & $\mathrm{L}$ \\
\hline
\end{tabular}

\subsection{The chemical composition and} microbiological test: The chemical analysis concerned about twenty populations, this is the dry matter (DM), the ash content (MM), the total nitrogen content by the method of
Kjeldahl (MAT) and fibres by the method of Van and Soest (NDF, ADF, HC, Ln). The microbiological test concerned 11 populations are inspired by the method advocated by Tilley and Terry in 1963. It is widely used in the world 
(Demarquilly and Jarrige, 1981). The total fulfilment requires:

- A Bain Marie system with $100 \mathrm{ml}$ test tubes, - A buffer solution of artificial saliva (Mc Dougall, 1948) whose role is to control the $\mathrm{pH}$ variations in the medium,

- A solution of trace elements (Kumaresan, 1976),

- A control forage whose in vivo digestibility is known with accuracy and accuracy, thus obtained with the international reference method. It serves to appreciate the activity of rumen juice,

- Inoculum of rumen (called "rumen juice").

- On the composition of mineral solutions The details of their composition are given in Tables 4 and 5 .

Table 4: Composition of Mc Dougall Artificial Saliva

(For a litre of solution)

\begin{tabular}{|l|l|}
\hline Products & Quantities (g) \\
\hline $\mathrm{Na}_{2} \mathrm{HPO}_{4}, 12 \mathrm{H}_{2} \mathrm{O}$ & 46.50 \\
\hline $\mathrm{NaHCO}$ & 49.00 \\
\hline $\mathrm{NaCl}$ & 2.35 \\
\hline $\mathrm{KCl}$ & 2.85 \\
\hline $\mathrm{CaCl}$ & 0.20 \\
\hline $\mathrm{MgCl}_{2}$ & 0.30 \\
\hline
\end{tabular}

To this litre of mother solution are added 4 litres of distilled water. The artificial saliva thus solution: $10 \mathrm{ml} / 1$ (Table 5) then saturated with obtained is enriched with the trace elements

Table 5: Composition of the solution of trace elements (/ 1).

\begin{tabular}{|l|l|l|l|}
\hline Elements & Amount (mg) & Salts used & Weight of salt (g) \\
\hline $\mathrm{Zn}$ & 300 & $\mathrm{Zn} \mathrm{SO}_{4} 7 \mathrm{H}_{2} \mathrm{O}$ & 13.196 \\
\hline $\mathrm{Co}$ & 3 & $\mathrm{CoCl}_{2}, 6 \mathrm{H}_{2} \mathrm{O}$ & 0.012 \\
\hline $\mathrm{Mn}$ & 615 & $\mathrm{Mn} \mathrm{SO}_{4}, \mathrm{H}_{2} \mathrm{O}$ & 1.889 \\
\hline $\mathrm{Fe}$ & 575 & $\mathrm{Fe} \mathrm{SO}_{4}, 7 \mathrm{H}_{2} \mathrm{O}$ & 2.862 \\
\hline $\mathrm{Se}$ & 0.6 & $\mathrm{Se}$ & 0.0006 \\
\hline $\mathrm{Cu}$ & 55 & $\mathrm{Cu} \mathrm{SO}_{4}, 5 \mathrm{H}_{2} \mathrm{O}$ & 0.216 \\
\hline $\mathrm{Mo}$ & 0.7 & $\mathrm{MO}_{2}\left(\mathrm{NH}_{4}\right)_{5}, 5 \mathrm{H}_{2} \mathrm{O}$ & 0.009 \\
\hline $\mathrm{I}$ & 1.4 & $\mathrm{I}$ & 0.0014 \\
\hline
\end{tabular}

2.4 On the control fodder: It is forage regardless of grass or legume whose digestibility of the dry matter has been accurately and accurately determined by the in vivo reference method with total harvest of faeces (CharletLevy, 1969), in order to calibrate the microbiological method.

- Calculation of digestibility:

$\operatorname{DigMS}(\%)=($ MSI - MSR / MSI $)$ X 100
Dig MS (\%): Digestibility of the dry matter.

MSI: Ingested dry matter MSR: dry matter refused

2.5 On the rumen juice: The mixed rumen juice of several animals is the inoculum of choice to recreate the conditions of food degradation in the rumen and thus evaluate them. Tilley and Terry, to standardize their method, had rumen juice whose quality and variability were controlled by a standard diet 
that juice donors received. These animals were lifelong carriers of rumen fistula through which this "standard" juice was taken. This procedure was expensive in fistulated animals and labour. But also the public opinion is more and more hostile to the invasive treatments that the animal research undergoes. Other alternatives include taking rumen juice directly to the slaughterhouse after slaughtering the animals (Borba et al, 2001).
2.6 On the operating mode: $0.5 \mathrm{~g}$ of each sample to be evaluated is treated twice in three trials (i.e. 6 data per sample). Table 6 presents alfalfa species and populations that have been subjected to this in vitro digestibility. They are taken from Table 7 and represent those whose biomass availability was sufficient to meet the biomass requirements of in vitro digestibility.

Table 6: Species and populations subject to in vitro digestibility.

\begin{tabular}{|l|l|}
\hline \multirow{4}{*}{ Mpecies } & Population code \\
\hline \multirow{4}{*}{ M.truncatula } & $\mathrm{C} 2$ \\
\cline { 2 - 2 } & $\mathrm{C} 58$ \\
\cline { 2 - 2 } & $\mathrm{S} 5$ \\
\hline \multirow{5}{*}{ M.intertexta } & $\mathrm{Tr} 238$ \\
\cline { 2 - 2 } & $\mathrm{Tr} 334$ \\
\hline & $\mathrm{I} 11$ \\
\cline { 2 - 2 } & $\mathrm{I} 31$ \\
\cline { 2 - 2 } & $\mathrm{I} 52$ \\
\hline & $\mathrm{I} 253$ \\
\cline { 2 - 2 } & $\mathrm{I} 58$ \\
\cline { 2 - 2 } & $\mathrm{I} 107$ \\
\cline { 2 - 2 } & $\mathrm{I} 756$ \\
\hline
\end{tabular}

This $0.5 \mathrm{~g}$ sample is placed in a $100 \mathrm{ml}$ microcentrifuge tube that receives $40 \mathrm{ml}$ of $\mathrm{Mc}$ Dougall artificial saliva enriched with trace elements and $10 \mathrm{ml}$ of rumen juice (taken from at least six sheep immediately after slaughter, at the El Harrach slaughterhouse transported in thermos bottles) .Before use, the juice is previously filtered through 5 layers of gauze. A sample of alfalfa hay, whose digestibility we have determined $(61.4 \%$ for $\mathrm{MS})$ using the international reference method, serves as a control of juice activity. A "white" tube, which only receives saliva and rumen juice, is also put in place. The tubes thus prepared are subjected for a few seconds to a current of $\mathrm{CO}_{2}$ (to reproduce the anaerobiosis conditions of the rumen), then closed by plugs crossed by a glass tube serving as a channel, itself surmounted by a cap. plastic with a slot for excess gas evacuation (Figure 1). 


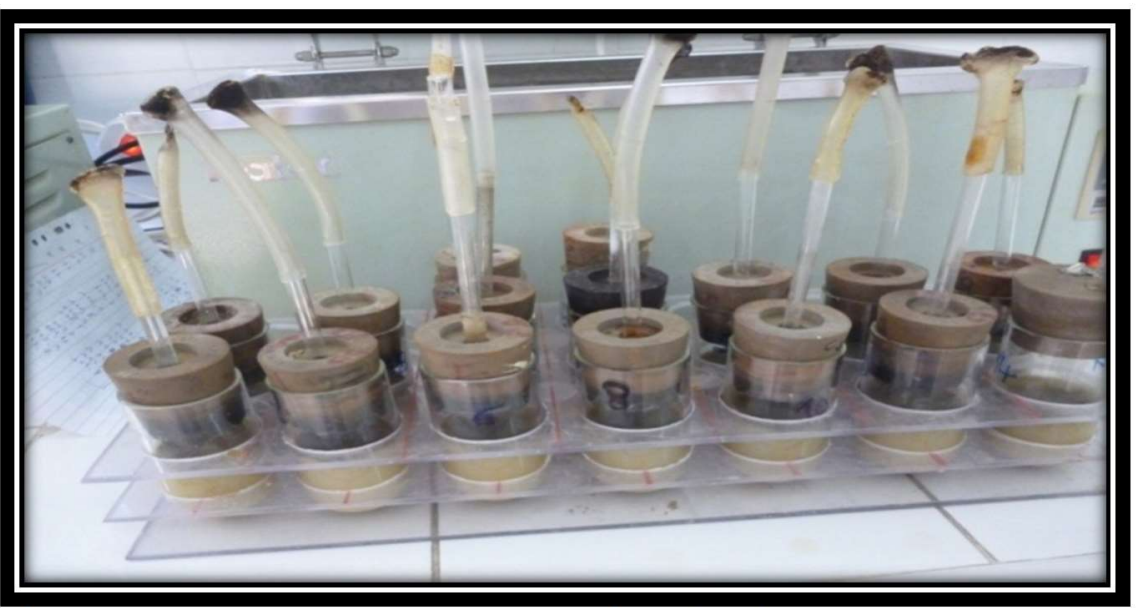

Figure 1: Prepared tubes, ready to be incubated

The tubes are then incubated in a bath set at 39

- $\mathrm{C}$ for 48 hours in the absence of air. This temperature is constantly monitored because followed by a thermometer. To allow us to

process all the samples at the same time and with the same juice, we used in parallel, two similar Marie baths. Figure 2 shows alfalfa incubation in progress.

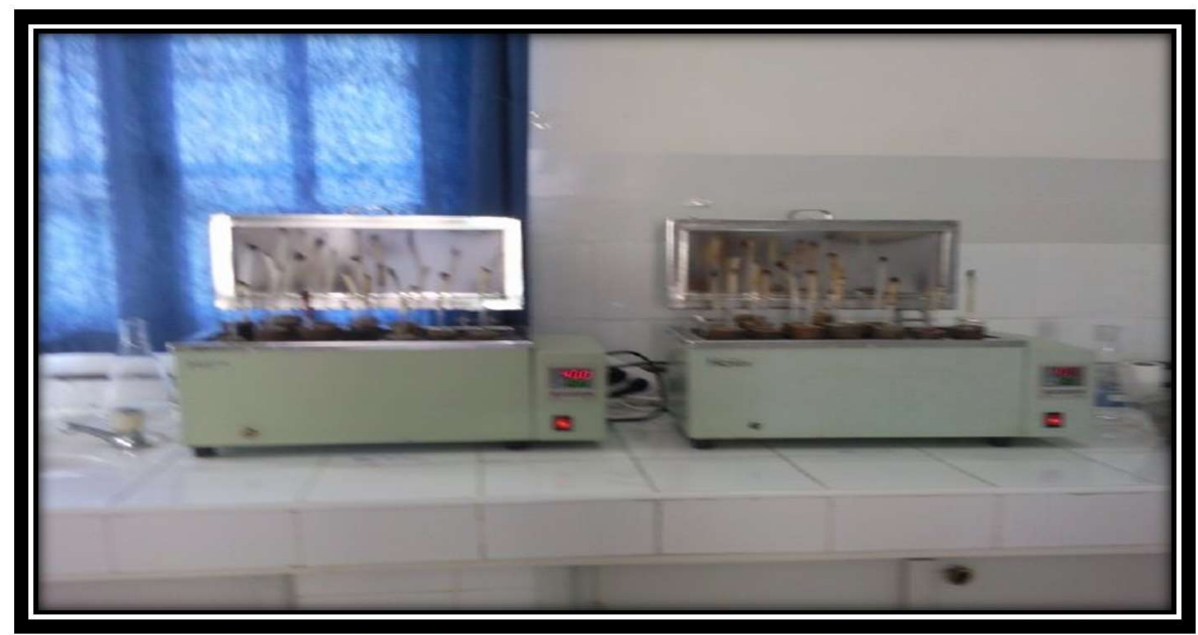

Figure 2: Tubes incubated at $39^{\circ} \mathrm{C}$ in the water bath

At the end of the incubation time, the fermentation is stopped by adding a few drops of mercuric chloride $\left(5 \% \mathrm{HgCl}_{2}\right)$ in each tube. Then, the medium is centrifuged for 10 minutes at $2500 \mathrm{G}$. After rinsing, they are centrifuged again for another 15 minutes. The pellet is recovered and taken up in $2 \%$ pepsin in $\mathrm{HCl}$ for 48 hours under the same incubation conditions as for the first phase. At the end of MSI - MSR this time the tubes are rinsed as before and put in the oven set at $105^{\circ} \mathrm{C}$ for 48 hours and weighed.

2.7 Calculation method: The determination of the residual MS makes it possible to calculate the proportion of the missing MS according to the following expression:

$$
\text { DIVMS }(\%)=100 x
$$


DIVMS = "In vitro" digestibility of the dry matter.

MSI $=$ Dry matter incubated.

MSR = Residual dry matter (unincubated MS -

MS of white).

\section{DISCUSSION AND RESULTS}

3.1 Chemical composition: The results in Table 7 indicate that the mineral content of the alfalfa is consistent as indicated by Goumiri et al. (1990), Porqueddu (2000), and Alane (2007). In our work, it varies from 9 to $14 \%$ of DM, very similar to that given by Meschy and Guéguen (1995): 8 to 15\%. For Jean-Blain (2002), it is a reflection of the soil that produces it; it is higher during the growth and accumulation phase of the plant. Alfalfa ash is also known to be rich in phosphorus, calcium, magnesium, and many micro-activating elements of microbial synthesis, such as zinc (FAO 2001, Daccord et al., 2001). The species $M$. truncatula $(\operatorname{Tr} 238)$ has the highest value $(18 \%)$ but this is not a particular advantage because the amount of organic matter correspondingly decreases the energy value of the forage. The nitrogen content is high with a maximum of $29 \%$ (S5) and a minimum of $20 \%$ (I107): the species $M$. ciliaris is the best provided in total nitrogenous materials (TNM or crud protein) with an average of $27 \%$ against $M$. intertexta: $23 \%$. The average, all populations combined, is $23 \%$, in agreement with that given by Mauriès (2003), for the stage bud-early bloom. The highest NDF content, $46 \%$ of the MS is recruited among $M$. intertexta (I253) quite, logically; ADF and ADL follow with 21 and 9\% as respective maximas for all populations. However, on average, the ADL content is only $5 \%$ with a minimum of $2.6 \%$ for C2 $M$. ciliaris.
The results are then corrected relative to control alfalfa hay.

2.8 Statistical analyzes of the results: All the results were the subject of a simple descriptive statistical analysis: mean, standard deviation, and coefficient of variation.

Finally, ANOVA tells us that only two components significantly discriminate our alfalfa populations: mineral substances (MS) and (TNM or crud protein) (Table 7). However, it is the wall and its components, which present the most important sources of variability (appreciated by the coefficient of variation): 31 ; 39 and 44 respectively for NDF, HC and ADL. The correlation matrix presented in Table 8, associates the membrane components (NDF), TNM and two other biometric parameters dry matter yield and number of rods per square meter. It shows the opposition between NDF and TNM. Similarly, at this stage of the flower bud, the quantity of MS produced is small, whereas this biomass is rich in nitrogen, which results in a negative correlation between these two variables. It is interesting to note, the positive sign of the correlation between the factors N.Tiges / $\mathrm{m}^{2}$ and ADF: the quantity of MS (thus indirectly lignin) increases parallel, with the age of the plant, just like NDF and ADL this, which confirms the results of Mauriès (2003). Similarly, the negative and significant correlation between $\mathrm{DMg} / \mathrm{m}^{2}$ and TNM \% DM is relevant, which can be expressed by the curve:

- N\% $=4.8$ (aerial MS) ${ }^{-0.32}$

Such a relationship indicates that any increase in alfalfa growth results in a decrease in its nitrogen value (Lemaire and Allirand, 1993).

Table 7: Chemical composition of alfalfa populations for which Div has been studied

\begin{tabular}{|l|l|l|l|l|l|l|l|l|}
\hline \multirow{2}{*}{ species } & \multirow{2}{*}{ Populations } & \multirow{2}{*}{ DM (\%) } & \multicolumn{2}{|l|}{$\mathbf{( \% )}$ DM } \\
\cline { 4 - 10 } & & & MS & MAT & NDF & ADF & HC & ADL \\
\hline \multirow{2}{*}{ M. ciliaris } & C2 & 90.09 & 11.76 & 24.81 & 20.79 & 16.86 & 3.93 & 2.59 \\
\cline { 3 - 9 } & C58 & 89.68 & 10.74 & 27.77 & 35.77 & 20.35 & 15.42 & 4.71 \\
\hline
\end{tabular}




\begin{tabular}{|c|c|c|c|c|c|c|c|c|}
\hline & S5 & 86.31 & 16.45 & 29.34 & 25.95 & 21.72 & 4.23 & 3.33 \\
\hline & average $\pm S D$ & 88.69 & 12.98 & 27.31 & 27.50 & 19.64 & 7.86 & 3.54 \\
\hline & & 0.21 & 3.05 & 2.30 & 7.61 & 2.51 & 6.55 & 1.08 \\
\hline & $\mathrm{CV}$ & 0.002 & 0.23 & 0.08 & 0.28 & 0.13 & 0.83 & 0.31 \\
\hline & $\operatorname{Tr} 238$ & 88.97 & 18.47 & 26.95 & 36.21 & 17.46 & 18.76 & 3.70 \\
\hline & $\operatorname{Tr} 334$ & 89.27 & 10.56 & 22.52 & 21.52 & 16.64 & 4.89 & 3.16 \\
\hline M. truncatula & average + SD & 89.12 & 14.52 & 24.74 & 28.87 & 17.05 & 11.83 & 3.43 \\
\hline & average $\pm S D$ & 0.21 & 5.59 & 3.13 & 10.39 & 0.58 & 9.81 & 0.38 \\
\hline & $\mathrm{CV}$ & 0.002 & 0.38 & 0.13 & 0.36 & 0.03 & 0.83 & 0.11 \\
\hline & I11 & 89.77 & 8.66 & 21.92 & 45.43 & 17.28 & 28.15 & 3.37 \\
\hline & I31 & 89.04 & 9.57 & 22.85 & 21.34 & 13.38 & 15.69 & 4.28 \\
\hline & I52 & 89.13 & 8.56 & 23.49 & 41.12 & 19.22 & 21.90 & 4.84 \\
\hline & I253 & 89.43 & 8.64 & 21.65 & 45.74 & 21.23 & 24.51 & 9.09 \\
\hline 19 intont & I58 & 88.05 & 9.18 & 23.93 & 20.85 & 15.85 & 5.00 & 2.65 \\
\hline M. intertexta & $\mathrm{I} 107$ & 89.78 & 8.02 & 20.37 & 28.11 & 15.21 & 17.91 & 4.19 \\
\hline & I756 & 89.62 & 9.05 & 25.11 & 36.38 & 16.50 & 19.88 & 6.70 \\
\hline & averace + SD & 89.26 & 8.81 & 22.76 & 34.14 & 16.95 & 19.01 & 5.02 \\
\hline & average $\pm S D$ & 0.61 & 0.50 & 1.59 & 10.74 & 2.61 & 7.43 & 2.20 \\
\hline & $\mathrm{CV}$ & 0.006 & 0.06 & 0.07 & 0.31 & 0.15 & 0.39 & 0.44 \\
\hline & CSR & 1.10 & 2.39 & 1.98 & 10.1 & 2.44 & 7.55 & 1.81 \\
\hline ANOVA & $\mathrm{R}^{2}$ & 0.06 & 0.57 & 0.55 & 0.11 & 0.23 & 0.36 & 0.18 \\
\hline ANOVA & $\mathrm{P}$ & 0.76 & 0.02 & 0.03 & 0.60 & 0.31 & 0.14 & 0.42 \\
\hline & Signification & NS & $* *$ & $* *$ & NS & NS & NS & NS \\
\hline
\end{tabular}

SD: standard deviation , CV: coefficient of variation, ${ }^{* *}: \mathrm{p}<0.001$; NS: not significant ( $\left.>>0.05\right)$; $\mathrm{R}^{2}$ : coefficient of determination; CSR: residual standard deviation.

Table 8: Matrix of correlations of some chemical and biometric parameters of the studied populations

\begin{tabular}{|l|l|l|l|l|l|l|l|}
\hline & NDF & ADF & HC & CF & ADL & $\mathbf{D M g} / \mathbf{m}^{2}$ & $\begin{array}{l}\mathbf{N} . s t e m s \\
/ \mathbf{m}^{2}\end{array}$ \\
\hline NDF & 1 & & & & & & \\
\hline ADF & 0.183 & 1 & & & & & \\
\hline HC & $0.876^{* * *}$ & -0.014 & 1 & & & & \\
\hline CF & -0.180 & 0.235 & $-0.316^{*}$ & 1 & & & \\
\hline ADL & $0.497^{* * *}$ & 0.111 & $0.449^{* *}$ & $-0.553^{* * *}$ & 1 & & \\
\hline DMg $/ \mathrm{m}^{2}$ & $0.40^{* *}$ & 0.10 & $0.35^{* *}$ & $0.34^{* *}$ & 0.05 & 1 & \\
\hline N. stems $/ \mathrm{m}^{2}$ & -0.08 & $0.40^{* *}$ & -0.17 & 0.16 & -0.28 & -0.20 & 1 \\
\hline TNM $\%$ DM & $-0.45^{* * *}$ & $0.31^{*}$ & $-0.42^{* *}$ & -0.20 & -0.22 & $-0.41^{* *}$ & $0.49^{* *}$ \\
\hline
\end{tabular}

$*: \mathrm{p}<0.05 ; * * 0.01 ; * * * 0.001$

3.2 In vitro digestibility: As can be seen in Table 9, the average in vitro digestibility of our Triade control is $60 \%$, very comparable to that measured in vivo $(61.4 \%)$ with a coefficient of variation (CV) of only $16.2 \%$. The difference between the trials is not significant. Just like the bath-Marie effect measured by the dry residue (of the incubated white) and the Div of the Triade witness. Clearly, the two baths used in parallel, have no effect on average on the result of the Div: the possible errors of manipulations offsetting. On the other hand, the dry residue of the juice which gives its residual solids content after $48 \mathrm{~h}$ of incubation, is different according to the day of sampling of the juice, therefore according to the test. Thus, this weight of the residue varies between $0.134 \mathrm{~g}$ for test 3 and $0.279 \mathrm{~g}$ for test 2 . This difference, on the one hand, reflects the nature of the food consumed by the juice-donor animals and on 
the other by residence time of these foods in

mixture of rumen juice from several animals). the rumen before harvest (although it is a

Table 9: Parameters of the conditions of achievements of in vitro digestibility

\begin{tabular}{|c|c|c|c|c|}
\hline & \multirow{2}{*}{ Div of the Witness (\%) } & \multirow{2}{*}{ Leftover juice (g) } & \multicolumn{2}{|c|}{ Effect bain-marie } \\
\hline & & & R.sec juice & $\operatorname{Div} T$ \\
\hline \multirow{2}{*}{ Test 1} & 46.12 & 0.201 & 0.201 & 46.12 \\
\hline & 59.98 & 0.191 & 0.267 & 76.39 \\
\hline \multirow{2}{*}{ Test 2} & 76.39 & 0.267 & 0.143 & 64.36 \\
\hline & 64.79 & 0.279 & 0.161 & 57.16 \\
\hline \multirow{2}{*}{ Test 3} & 64.36 & 0.143 & 0.191 & 59.98 \\
\hline & 58.27 & 0.134 & 0.279 & 64.79 \\
\hline \multirow{2}{*}{ Test 4} & 57.16 & 0.161 & 0.134 & 58.27 \\
\hline & 52.77 & 0.162 & 0.162 & 52.77 \\
\hline Mean \pm SD & $59.98 \pm 9.72$ & $0.19 \pm 0.059$ & $0.19 \pm 0.059$ & $59.98 \pm 9.72$ \\
\hline $\mathrm{CV}$ & 0.162 & 0.31 & 0.31 & 0.162 \\
\hline CSR & 6.92 & 0.006 & 0.06 & 9.63 \\
\hline $\mathrm{R}^{2}$ & 0.66 & 0.99 & 0.0006 & 0.02 \\
\hline $\mathrm{P}$ & $\begin{array}{l}0.19 \\
\text { NS }\end{array}$ & $\begin{array}{l}0.0001 \\
* * *\end{array}$ & $\begin{array}{l}0.95 \\
\text { NS }\end{array}$ & $\begin{array}{l}0.75 \\
\text { NS }\end{array}$ \\
\hline
\end{tabular}

This difference has no repercussions on the value of the measured Div because; the method of calculation of the Div makes it possible to deduct the residual dry weight of the inoculums of the dry residue of the tubes, which have received the samples of alfalfa. In vitro digestibility of the dry matter of the studied populations considered first by test, the recorded digestibility values are equal to or greater than $70 \%$ : 75; 73; 74; 79 (respectively for tests 1 to 4 ) and on average, $75 \%$. The average digestibility per species is $77 ; 73$ and $75 \%$ for $M$ ciliaris, $M$ truncatula and $M$ intertexta. In the literature, some in vitro digestibility performed on annual alfalfa show values at the vegetative stage, budding or early flowering of the order of $70 \%$, which is in agreement with our results obtained at the early flowering stage. Thus, Brownlee and Denney (1985) report that, in vitro, $M$. polymorpha cv. Cyprus was $66 \%$ against $71 \%$ for $M$. truncatula cv. Jemalong.
Jones and McLeod (1971) on M truncatula recorded a digestibility of DM of $72 \%$ at the vegetative stage of the plant, $60 \%$ at flowering and $30 \%$ at senescence. The same authors observed that M. scutellata had a digestibility of $78 \%$ at the vegetative stage and $50 \%$ at the end of seed maturation. A digestibility equal to or greater than $70 \%$ is therefore proven for annual alfalfa at an early stage of harvest. Like the chemical composition (decrease of TNM, increase of NDF), the digestibility drops with the age of the plant. These levels of digestibility, on average between 70 and $80 \%$ that we obtained and confirmed by the literature seems to be a characteristic of all the populations that we have treated because even if significant differences are observed between tests and for the synthesis of all In the trials (Table 10), only $51 \%$ of the variations in digestibility are explained by alfalfa populations.

Table 10: Value of digestibility of studied alfalfa populations

\begin{tabular}{|l|l|l|l|l|l|l|l|}
\hline Species & Populations & $\begin{array}{l}\text { Test } \\
\text { digestibility } \\
1\end{array}$ & $\begin{array}{l}\text { Test } \\
\text { digestibility } \\
2\end{array}$ & $\begin{array}{l}\text { Test } \\
\text { digestibility } \\
3\end{array}$ & $\begin{array}{l}\text { Test } \\
\text { digestibility } \\
4\end{array}$ & $\begin{array}{l}\text { average of } \\
\text { the tests }\end{array}$ & $\begin{array}{l}\text { average } \\
\text { species }\end{array}$ \\
\hline M. ciliaris & C2 & 87.59 & 81.83 & 75.52 & 70.08 & 78.75 & 77.14 \\
\hline
\end{tabular}




\begin{tabular}{|c|c|c|c|c|c|c|c|}
\hline & C58 & 72.79 & 73.57 & 79.97 & 82.49 & 77.20 & \\
\hline & S5 & 79.64 & 66.99 & 74.56 & 80.64 & 75.46 & \\
\hline \multirow{2}{*}{$\begin{array}{l}\text { M. } \\
\text { truncatula }\end{array}$} & $\operatorname{Tr} 238$ & 69.93 & 65.51 & 70.02 & 74.28 & 69.94 & \multirow{2}{*}{73.34} \\
\hline & Tr334 & 77.28 & 73.54 & 73.66 & 82.53 & 76.75 & \\
\hline \multirow{13}{*}{$\begin{array}{l}M . \\
\text { intertexta }\end{array}$} & I11 & 74.04 & 67.46 & 74.45 & 80.22 & 74.04 & \multirow{7}{*}{74.60} \\
\hline & I31 & 76.33 & 72.93 & 76.20 & 79.87 & 76.33 & \\
\hline & I52 & 76.34 & 75.39 & 74.57 & 79.07 & 76.34 & \\
\hline & I253 & 64.5 & 77.18 & 77.85 & 80.57 & 75.02 & \\
\hline & I58 & 70.0 & 75.80 & 71.12 & 79.00 & 73.98 & \\
\hline & I107 & 69.4 & 65.19 & 68.09 & 79.83 & 70.63 & \\
\hline & I756 & 73.21 & 76.06 & 75.34 & 78.91 & 75.88 & \\
\hline & Mean \pm SD & $74.72 \pm 6.7$ & $72.62 \pm 6.9$ & $74.28 \pm 4.32$ & $78.96 \pm 4.52$ & $75.3 \pm 2.60$ & $75.17 \pm 2.34$ \\
\hline & $\mathrm{CV}$ & 0.09 & 0.09 & 0.06 & 0.06 & 0.034 & 0.031 \\
\hline & RSE & 7.71 & 5.53 & 4.0 & 4.08 & 6.01 & - \\
\hline & $\mathrm{R}^{2}$ & 0.31 & 0.62 & 0.55 & 0.57 & 0.51 & - \\
\hline & $\mathrm{P}$ & 0.50 & 0.16 & 0.31 & 0.26 & 0.44 & - \\
\hline & - & $*$ & $* * *$ & ** & $* *$ & $* *$ & - \\
\hline
\end{tabular}

$*: \mathrm{p}<0.05 ; * * 0.01 ; * * * 0.001$

In light of these results, it seems that in practice, variations between populations and species are low: 3.4 and 3.1\% respectively. The criterion of Div at an early stage of the plant does not seem to strongly discriminate populations in terms of criteria for selection. Other indicators such as: yield per hectare, earliness (determining the number of cuts), leafto-stem ratio, digestibility of the stem, ingested quantities among others offer a wide range of variability (Abdekafi and Marrakchi. 2000), sources of opportunities and genetic wealth. The strong characteristic of this alfalfa is the rapid drop in their digestibility with the progress of the stages, in strict correlation with the chemical composition. The strong characteristic of this alfalfa is the rapid drop in their digestibility with the progress of the stages, in strict correlation with the chemical composition. Nevertheless, the digestibility of alfalfa, despite its high content of TNM, is lower than that of Poaceae at the same stage of development (Crespo, 1977) and many scientific voices are raised for the improvement

\section{CONCLUSION}

This work was intended to contribute to the deepening of knowledge in the species and populations of annual alfalfa annuals of Algeria. It is indeed judicious to note that, despite a of this digestibility by selection. By combining high production and digestibility (Demment et al, 1986, Emile and Traineau, 1993, Julier and Huyghe 1998). This digestibility could be achieved by improving the ratio of leaves to stems and stalk digestibility (53\% versus 69\% for the whole plant). Moreover, the structural variability of lignin (well localized in the stem) leaves margins for an improvement of its solubility and therefore of its degradation in the rumen (Jouanin and Lapierre, 2006). Let us note, however, that experience shows that there is always an antagonism between quality and quantity. However, the quantity expressed per hectare remains an economic indicator of weight for the farmer. The point at which these two curves intersect will be all the easier to achieve as we have in Algeria a great potential for natural genetic variability: to choose in diversity (Chehat, 1988, Abdekafi and Marrakchi, 2000, Khelifi et al. 2006), in contrast to countries where the pressure of selection has led to damaging genetic erosion (Lafon et al., 1996).

large body of knowledge accumulated for 50 years by researchers, alfalfa cultivation has not significantly progressed in Algeria, which is far behind Tunisia Morocco Egypt and Turkey. 
Based on the phenological and biometric criteria on which the quality of alfalfa depends, such as: the nitrogen content (TNM), the production per hectare of TNM, dry matter (DM). There are several points:

Let us note, however, that experience shows that there is always an antagonism between quality and quantity. However, the quantity expressed per hectare remains an economic indicator of weight for the farmer. The point at which these two curves intersect will be all the easier to achieve as we have in Algeria a great potential for natural genetic variability: to choose in diversity (Chehat, 1988, Abdekafi and Marrakchi, 2000, Khelifi et al. 2006), in contrast to countries where the pressure of selection has led to damaging genetic erosion (Lafon et al., 1996).

- The twenty or so populations of local annual alfalfa we studied showed a great genetic variability of the studied parameters, which constitutes an important genetic capital in which the breeder could draw at leisure.

\section{REFERENCES}

Abdelguerfi, A., Abdelguerfi-Berrekia, R: 1987. Le système Blé-Medicago: pourqoi, où et comment.R.Céréaliculture $\mathrm{n}^{\circ} 16 \cdot \mathrm{p} 44-$ 45

Abbelkefi, A and Marrakchi, H: 2000. Les ressources phylogénétiques fourragères et pastorales de l'érosion à la conservation. Cah opt méd vol .45, 1527.

Alane, F: 2007.Valeur nutritive des légumineuses fourragères cas des luzernes (Genre Medicago).Thése de magister .INA; 96p

Borba, A.E.S., Correia, P. J.A., Fernandes, J.M.M., Borba, A.F.R.S:2001.Comparison of three sources of inocula for predicting apparent digestibility of ruminant feedstuffs.Anim. Res. 50, 265-273

Brownlee, $H$ and Denney, G.D:1985. Evaluation of medics under continuous
- Thus, the TNM content averages $27 \%$ for $M$ ciliaris (peak at $30 \%$ for the $\mathrm{S}_{5}$ population). The production of TNM brought to the ha and for a harvest only is on average, of the international level with 1 ton. Some populations of $M$ intertexta such as $\mathrm{I}_{11}$ and $\mathrm{I}_{31}$ approach or exceed 1.4 tonnes. It is the same for the production of MS: 6 tons / ha for $\mathrm{I}_{31}$ and $\mathrm{I}_{52} ; 5$ tons / ha for $\mathrm{I}_{253}$. $\mathrm{C}_{52} \mathrm{Se}$ also distinguishes with not far from 5 tons.

- For these quality criteria, the Australian $M$ truncatula (CV Jemalong), Australian, was totally unsuitable with 0.3 tons of DM per ha, contrary to the Turkish control $M$ muricoleptis (pop Aus) at the height of our best populations with respective production of TNM and MS of 1.3 and 5.3 tons.

- The last quality of alfalfa: its digestibility (Div) resulting in its energy value is also very honourable and not very variable (3.1\%) between species: average $75 \%$ with $77 \%$ for $M$ ciliaris. These populations have a better place in the ley farming system than of late harvested vetch-oats.

grazing with sheep in central-western New South Wales. Aust. J. Exp. Agric., 25: 311-319.

Charlet-Levy, G: 1969 .Method for determination of digestibility coefficients of feed for ruminant. Commission on animal nutrition, report 1:33p

Chehat, F: 1988. Recherche des ressources phylogénétiques et recherché agronomique. Ann .Inst .Nat .Agr El Harrach Vol (12).26-25.

Crespo, D.G:1977. Quelques aspects de l'amélioration des productions pastorales et fourragères en Corse. Elvas Portugal.

Daccord, R., Arrigo .Y. Kessler. J., Jeangros .B. Scehovic .J. Xschubiger.F. Lehmann: 2001.Valeur nutritive des plantes des prairies. Revue Suisse Agric .33(4).141146 
Demarquilly .C and Jarrige.R: 1981. Panorama des méthodes de prévision de la digestibilité et de la valeur énergétique des fourrages. In: Prévision de la valeur

Demment, M.W., Teuber L.R., Bourqued.P. Phillips.D.A :1986." Changes in forage quality of improved populations", Crop Sci., 26, 1137-1143.

Emile, J.C., Traineau, R: 1993. Effet de la variabilité génétique sur la digestibilité in vivo de la luzerne. Fourrages (134), 251254.

FAO,

2001 .http://www .fao.org / docrep/W 1808/W1808f05.htm

Goumiri, R., Abdelguerfi. A., LongoHammouda, F.Z: 1990. Contribution à l'étude des espèces spontanées du genre Medicago en Algérie. Analyses chimiques du fourrage au stade végétatif. Rev. Céréaliculture, 22: 25-27.ITGC, 1979. Les légumineuses fourragères. $\mathrm{La}$ luzerne (Medicago sativa). Rev. Céréaliculture, 10: 27-31.

Hassen ,H., Mezni ,M., Seklani,H., Zoghlami ,A: 1996.Synthèse e des travaux de recherché réalisés sur les Medicago à l'Institut National de la Recherche Agronomique de Tunisie in Genier G. ( ed.) , Prosperi J.M. ( ed.) . The Genus Medicago in the Mediterranean region: Current situation and prospects in research Zaragoza: CIHEAM Cahiers Options Méditerranéennes; n. 18 Pages 31- 37

Greuter, w: 2001. Diversity of Mediterranean island floras. - Bocconea 13: 55-64. 2001. - ISSN 1120-4060.

Heyn, C.C: 1963. The annual species Medicago. Palestine.154.

Jean-Biain C: 2002. Introduction à la nutrition des animaux domestiques 424p.

Jones, R.M. and McLeod, M.N:1971.Changes in nutritive value throughout the growth cycle of snail medic (Medicago scutellata). J. Aust. Inst. Agric. Sci., 37: 63-6
Jouanin, L et Lapierre, C: 2006.Avantages et limites d'Arabidopsis thaliana pour l'étude des premières étapes de la lignification. Cahiers Agricultures vol. 15, $\mathrm{N}^{\circ}$ 2, 179185.

Julier, B., Guines, F., Ecalle. C., Emile J.C., Lila .M. Briand .M. Huyghe, C: 2003. Eléments pour une amélioration génétique de la valeur énergétique de la luzerne. Fourrages (2003) 173, 49-61

Julier, B., Huyghe, C: 1998. Variabilité génétique pour la digestibilité de la luzerne relation avec la production de matière sèche et la proportion de feuilles. Fourrages 154, 261-268

Khelifi,H. E.,Abdelguerfi-

Laouar.M .,M'Hammedi Bouzina .M .,Bellague .D., Chedjerat .A., Abbas,K., Huguet,T .,Aouani,M .E., Abdelguerfi,A : 2006.Genetic variability within and among natural populations of Medicago laciniata Mill(Fabacea) investigated by quantitave traits. Workshop international sur diversité des Fabacées fourragères er leurs symbiotes: Applications biotechnologiques, agronomiques et environnementales .Alger, 1922Février2006.

Kumaresan, A: 1976. Interactions entre le zinc et les microorganismes du rumen chez le mouton recevant de l'urée comme source unique d'azote. Thèse Doct. Univ., Toulouse.

Lafon, J-P, C., Tharaud-Prayer, G., Lévy.c:1996.Biologie des plantes cultivées .ed Lavoisier.233p.

Lemaire, G., Allirand .J.M:1993. «Relation entre croissance et qualité de la Luzerne: interaction entre génotype -mode d'exploitation ».Fourrages, $\quad 134,183$ 198.

Mauriès, M: 2003. Luzerne: culture, récolte, conservation, utilisation http://www.

McDougall, E: 1948. Studies on Ruminant Saliva. The Composition and Output of 
Sheep's Saliva. Biochemical Journal, 43, 99-109.

Meschy, F., Guéguen, L: 1995. Ingestion et absorption des éléments minéraux majeurs. In R. Jarrige., 1995.Nutrition des ruminants domestiques. 722-758. INRA, Paris

Porqueddu, C: 2001 .Screening germplasm and varieties for forage quality: Cons traints and potentials in annual medics in Delgado I. (ed.), Lloveras J. (ed.) Quality in lucerne and medics for animal production .Zaragoza : CIHEAM Options Méditerranéennes : Série A. Séminaires Méditerranéens; n. 45 pages $89-98$

Tilley J.M et Terry R. A: 1963. A two -stage technique for the in vitro digestion of forage crops.J.Brit.Grassl.Soc. 18,104111. 